УДК 532.529

\title{
ІНТЕНСИФІКАЦІЯ АЕРАЦІЙНО-ОКИСЛЮВАЛЬНИХ ПРОЦЕСІВ В ТЕХНОЛОГІЇ ОЧИЩЕННЯ ПИТНОЇ ВОДИ ЗА РАХУНОК НОВОГО ТЕПЛОМАСООБМІННОГО ОБЛАДНАННЯ
}

\author{
Долінський А.А., Д.т.н., академік НАНУ, Ободович О.М., Д.т.н., Переяславцева О.О., к.т.н., \\ Сидоренко В.В., к.т.н.
}

Інститут технічної теплофізики НАН Украӥни, вул. Желябова, 2а, Київ, 03680, Україна

У статті представлені експериментальні дані по знезалізненню артезіанської води киснем повітря в тепломасообмінній аераційноокиснювальній установці роторного типу. Встановлено залежності швидкості знезалізнення від параметрів обробки.
В статье представлены экспериментальные данные по обезжелезиванию артезианской воды кислородом воздуха в тепломассообменной аэрационно-окислительной установке роторного типа. Установлены зависимости скорости обезжелезивания от параметров обработки.
The article presents experimental data on the deferrization of artesian water by air oxygen in a heat and mass transfer, aeration-oxidative setup of the rotor type. Dependences of the rate of deferrization on processing parameters are established.

Бібл. 7, рис. 4, табл. 1.

Ключові слова: артезіанська вода, знезалізнення, аератор-окислювач, частота пульсацій, швидкість зсуву потоку.

Джерелом питного водопостачання є поверхневі та підземні артезіанські води. Для України основним поверхневим джерелом питної води є річка Дніпро. Проте в останні 20 років $з$ причини поганої екологічної обстановки та сильних забруднень вода р. Дніпро стає малопридатною для питного водопостачання.

Кожен день в Дніпро скидається 3 майже 10 тис. підприємств 10 км $^{3}$ стічних вод , 3 яких $15 \%$ без жодного очищення, а решта недоочищується. В табл.1 представлений відсоток перевищення граничнодопустимих концентрацій забруднюючих речовин, що скидаються у Дніпро.

В зв'язку 3 тим, що режим течії Дніпра перетворився в озерний, різко погіршився водообмін i шкідливі речовини практично не виносяться течією в море. Через велику кількість забруднень вода 3 Дніпра та інших поверхневих водоймищ України важко піддається очищенню 3 метою використання для потреб питного водопостачання. Тому, за останнє десятиріччя в питному водопостачанні м. Києва доля артезіанських вод збільшується. Якщо не рубежі 70-80-х років 20-го сторіччя питне водопостачання м. Києва здійснювалось на 80 \% 3 поверхневих водоймищ (р. Дніпро, Десна), то в даний час через забруднення річок, більш доцільним $є$ використання артезіанських вод (до 60 \% від загальної кількості).

Артезіанські водоносні шари знаходяться, зазвичай, на значній глибині - від декількох десятків до сотень метрів від поверхні землі. Вони надійно захищені від поверхневого органічного забруднення. Пласти водоносних порід знаходяться між водотривкими шарами. Контакт води 3 підземними мінералами збагачує іiі різноманітними солями. Частіше за все в артезіанській воді міститься велика кількість заліза, марганцю, сірководню, вуглекислого газу.

Для очищення артезіанської води від вищевказа- них 3'єднань найчастіше використовується аераційноокислювальні методи.

Метою даної роботи є інтенсифікація аераційноокислювальних процесів в технології очищення артезіанської води за рахунок використання нової тепломасообмінної установки роторного типу.

Аераційні методи являють собою найбільш простий прийом знезалізнення природних вод, що полягає в насиченні води киснем повітря з метою окислення заліза (II) і переведення його в важко розчинний гідроксид заліза (III). Найчастіше цей метод застосовують при наявності у воді гідрокарбонатів і сульфатів заліза (II) $[1,2]$.

До основних аераційних методів знезалізнення води відносять наступні:

- "спрощена аерація" з подальшим фільтруванням через зернисте завантаження;

- "глибока аерація" з подальшим фільтруванням;

- "метод" Віредокс".

Метод спрощеної аерації заснований на здатності води, що містить залізо (II) і розчинений кисень, при фільтруванні через зернистий шар (пісок, антрацит, керамічна крихта) виділяти залізо на поверхні зерен, утворюючи каталітичну плівку з гідроксидів дво- і тривалентного заліза. Ця плівка активно інтенсифікує процеси окислення і виділення заліза з води [3].

Для збагачення води киснем можуть застосовуватися різні способи, наприклад злив води 3 висоти 0,5 м в кишеню фільтра зі швидкістю $2,5 \ldots 3 \mathrm{~m} / \mathrm{c}$.

За стехіометричним співвідношенням на окислення 1 мг двовалентного заліза витрачається 0,143 мг кисню. В установках знезалізнення для забезпечення досить високої швидкості хімічної реакції, відповідно до оптимальних параметрів фільтруючого завантаження, вміст кисню, розчиненого у воді, має становити $0,5 \ldots 0,9$ мг на 1 мг двовалентного заліза. У тих випадках, 
коли потрібно одночасно збагатити воду киснем і видалити частину вільного діоксиду вуглецю, раціонально застосовувати градирні, завантажені дерев'яною насадкою.

У багатьох випадках раціональним для збагачення води повітрям виявляється водоповітряний ежектор. Тиск (напір) на манометрі до ежектора 320 кПа (3,2 атм). Те ж, після ежектора 80 кПа (0,8 атм). Продуктивність ежектора по повітрю 7,2 м³/год. Витрата води 27 м³/год. У міру зростання опору в фільтруючому завантаженні і збільшення протитиску після ежектора його продуктивність знижується.

При окисленні двовалентного заліза киснем в природній воді протікають наступні фізико-хімічні процеси:

1) перенесення кисню через прикордонний газовий дифузний шар до кордону фаз вода-повітря;

2) перенесення кисню через прикордонний шар води від кордону фаз вода-повітря;

3) дифузія кисню в об’ємі води;

4) гомогенна реакція окислення;

5) гідроліз тривалентного кисню.
Знезалізнення води є процесом масообміну, ускладненим хімічними реакціями. Швидкість хімічного перетворення визначається швидкістю транспорту речовини i теплоти до зони реакції і швидкістю реакції. Процеси масо-і теплообміну які супроводжуються хімічною реакцією, можуть протікати в дифузійної, кінетичної або проміжних областях. В дифузійній області процес лімітується швидкістю транспорту теплоти i речовини в зоні реакції і реалізується при великих швидкостях хімічної реакції. Навпаки, процес, що протікає в кінетичній області, лімітується швидкістю хімічної реакції і реалізується при великих швидкостях транспорту теплоти і речовини до зони реакції.

3 вищевикладених матеріалів випливає, що процес знезалізнення води залежить від швидкості реакції окислення двовалентного заліза киснем повітря у водному розчині.

Процес окислення двовалентного заліза киснем повітря, в свою чергу, залежить від швидкості масопереносу (розчинення і доставки кисню) в дифузійної області. Дискретно-імпульсне введення енергії інтенсифікує процеси масо- і теплопереносу [4,5].

Табл. 1. Перевищення граничнодопустимої концентрації речовин, що скидаються (ГДК), \%

\begin{tabular}{|c|c|c|c|c|c|c|}
\hline \multirow{2}{*}{$\begin{array}{c}\% \\
\text { перевищення }\end{array}$} & \multicolumn{6}{|c|}{ Назва } \\
\cline { 2 - 7 } & Феноли & Мідь & Цинк & Важки метали & $\begin{array}{c}\text { Азотисті } \\
\text { 3’єднання }\end{array}$ & Радіонукліди \\
\cline { 2 - 7 } & 200 & 700 & 800 & 900 & 600 & 150 \\
\hline
\end{tabular}

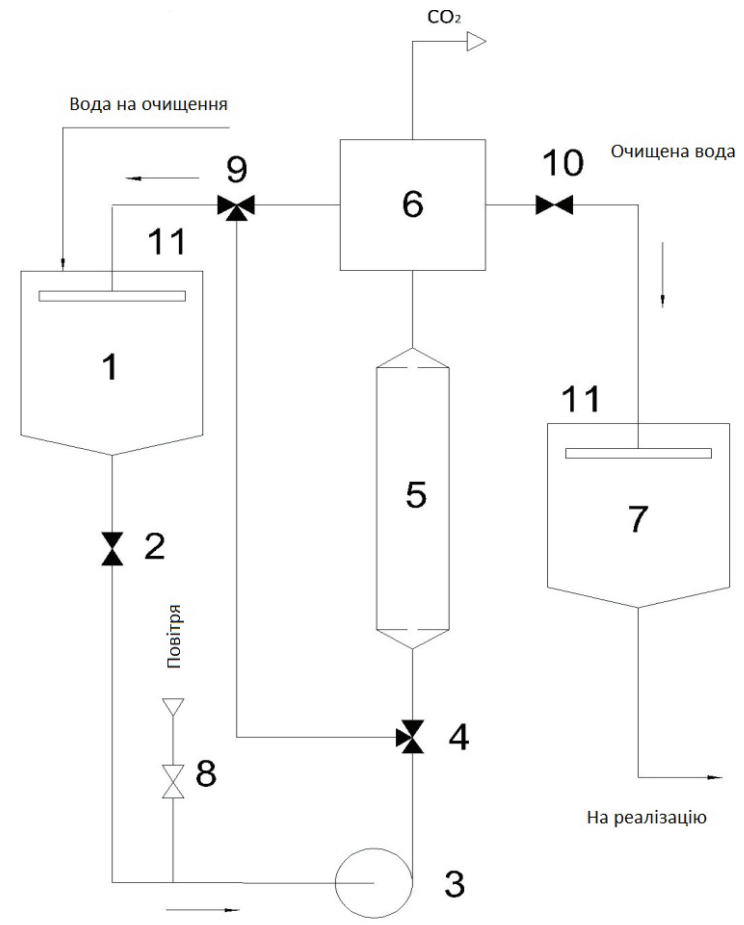

Рис. 1. Схема знезалізнення води за допомогою аератора-окислювача роторного типу. 1 - збірник-накопичувач; 2,8,10 - двоходовий кран; 3 - аератор-окислювач роторного типу; 4, 9 - триходовий кран; 5 - фільтраційно-окислювальна колона; 6 - розширювальний бачок; 7 -бак для очищеної води; 11 - розпилювальна голівка. 
Для поліпшення процесів знезалізнення води в Інституті технічної теплофізики НАН України розроблено схему очищення з дискретно-імпульсним введенням енергії, який реалізується за допомогою роторнопульсаційних апаратів (рис. 1).

Знезалізнення води, згідно розробленої схеми, здійснюється наступним чином. Артезіанська вода, що надходить на очистку, подається в збірник-накопичувач (1). Після відкриття двохходового крана (2) вода надходить в аератор-окислювач роторного типу (3). Подача повітря в приймальний патрубок апарату здійснюється шляхом відкриття крана (8). Таким чином, в аераторокислювач роторного типу надходить водно-повітряна суміш. У водно-повітряній суміші, що обробляється в апараті, відбувається розчинення кисню, а також частково реакції окислення $\mathrm{Fe}^{2+}$ в $\mathrm{Fe}^{3+}$ і гідролізу до $\mathrm{Fe}(\mathrm{OH})_{3}$. Після цього, водно-повітряна суміш прямує в фільтраційно-окислювальну колону (5), яка може бути заповнена піском або вугіллям різних фракцій (велика знизу, дрібна згори). У колоні відбуваються процеси остаточного окислення, гідролізу і очищення води від гідроксиду заліза $\mathrm{Fe}(\mathrm{OH})_{3}$, що випав в осад. Після проходження колони (5), очищена від заліза вода надходить в розширювальну ємність (6), де 3 неї видаляється діоксид вуглецю, що утворився в результаті реакції. Знезалізнена вода з нижньої частини ємності (6) через двохходовий кран (10) надходить до збірника очищеної води і далі йде на реалізацію.

Необхідно відзначити, що знезалізнення води відбувається в прямотоці за один прохід через аераторокислювач роторного типу, фільтраційно-окислювальну колону і розширювальну ємність. Для більш високо- го очищення води від заліза, установка може працювати в режимі рециркуляції. У цьому випадку після розширювальної ємності (6) через триходовий кран (9) і розпилювальну голівку (11) вода прямує в збірникнакопичувач (1). Рециркуляція може проходити за кілька циклів до досягнення необхідної концентрації заліза.

Аераційно-окислювальна установка роторного рипу була апробована в умовах Червонослобідського спиртового заводу концерну "Укрспирт".

Для технологічних цілей на вищезгаданому підприємстві використовувалась вода 3 артезіанських свердловин глибиною $200 \ldots 250$ м. За своїми фізикохімічними показниками ця вода не відповідає вимогам ДСТУ на питну воду. Вміст заліза в воді, що досліджувалась, досягав 3,5 мг/л при граничнодопустимій концентрації не більше 0,3 мг/л. Для знезалізнення води Черврнослобідського спиртового заводу була використана аераційно-окислювальна установка роторного типу.

При проведенні експерименту було досліджено вплив конструктивних особливостей роторнопульсаційного вузла на ефективність знезалізнення води.

Одним 3 показників, які впливають на гідродинамічну обстановку всередині аератора-окислювача, $\epsilon$ кутова швидкість обертання ротора. При проведенні експерименту кутову швидкість ротора міняли від 35 до 55 об/с. Початкова концентрація іонів заліза в об'єкті дослідження складала 3,5 мг/л. Графік зміни концентрації іонів заліза в воді від кількості циклів обробки при різних швидкостях обертання ротора представлений на рис. 2.

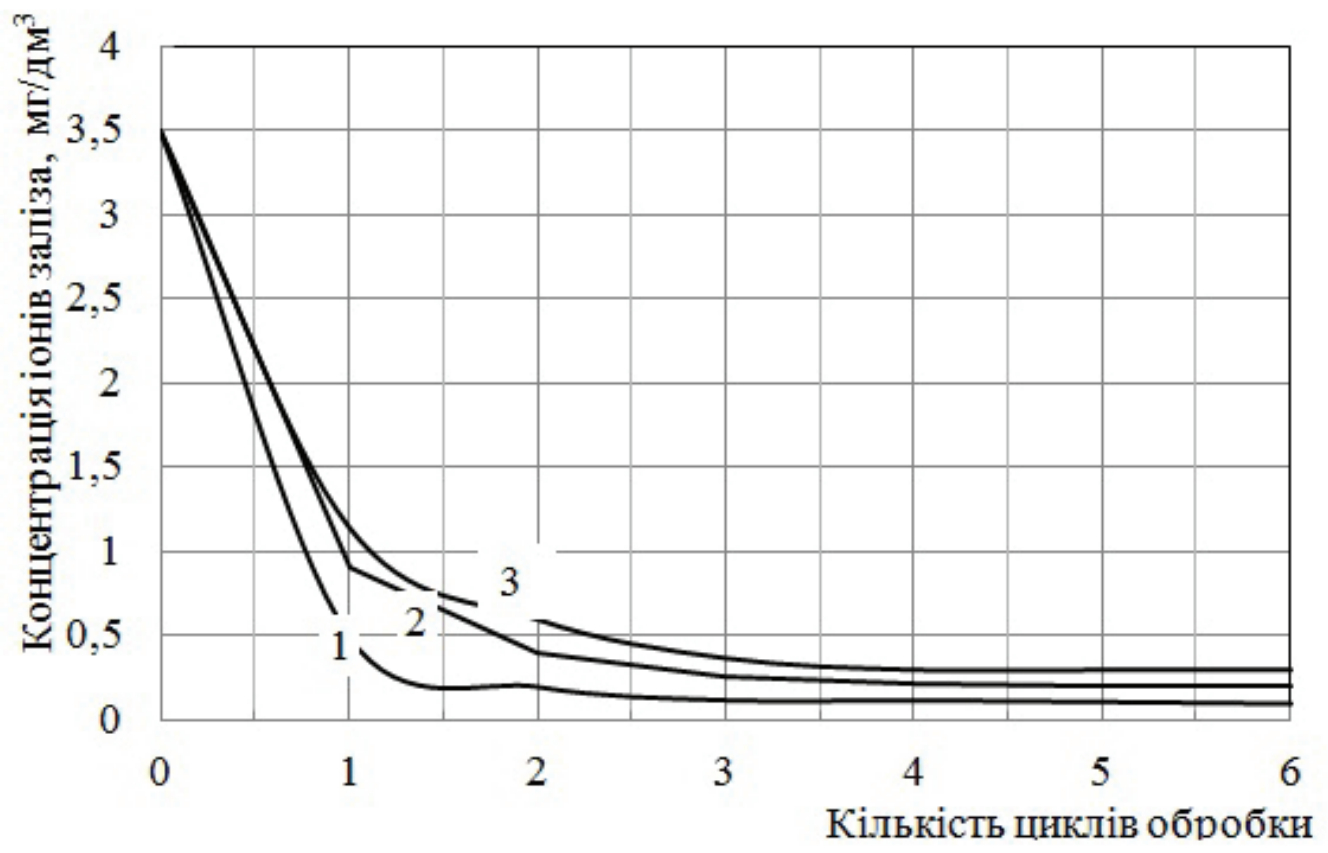

Рис. 2. Залежність зміни концентрації іонів заліза в воді від кількості циклів обробки при шиидкостях обертання ротора: $1-55 ; 2-45 ; 3-35 о б / c$. 
3 рис. 2 видно, що обробка води в аераторіокислювачі дозволяє ефективно знижувати концентрацію іонів заліза у воді. Так, при кутовій швидкості обертання ротора 55 об/с концентрація іонів заліза за один прохід води через робочі органи апарата (один цикл) знижується 3 3,5 до 0,25 мг/л. Зі зменшенням кутової швидкості від 45 та 35 об/с необхідно збільшувати кількість циклів обробки для досягнення бажаного результату. (не більше 0,3 мг/л).

Ротор в аераторі-окислювачі виконаний у вигляді циліндру з поперечними щілинними отворами розміром 40,0 x 3,0 мм. Їх кількість складає 60. Статор виконаний аналогічно ротору 3 таким самим кількістю отворів. Зазор між статором і ротором складає 150 мкм [6,7].

Виходячи з конструктивних особливостей статора та ротору, воду в установці можна обробляти 3 різною частотою пульсацій. Частота пульсацій визначається множенням кутової швидкості обертання ротора на кількість прорізів в роторі та вимірюється в кГц.

Наступним етапом досліджень було встановлення залежності концентрації заліза від кількості циклів обробки з різноманітною частотою пульсацій (рис. 3). 3,0 кГц.

Частоту пульсацій змінювали в межах 2,0; 2,5;

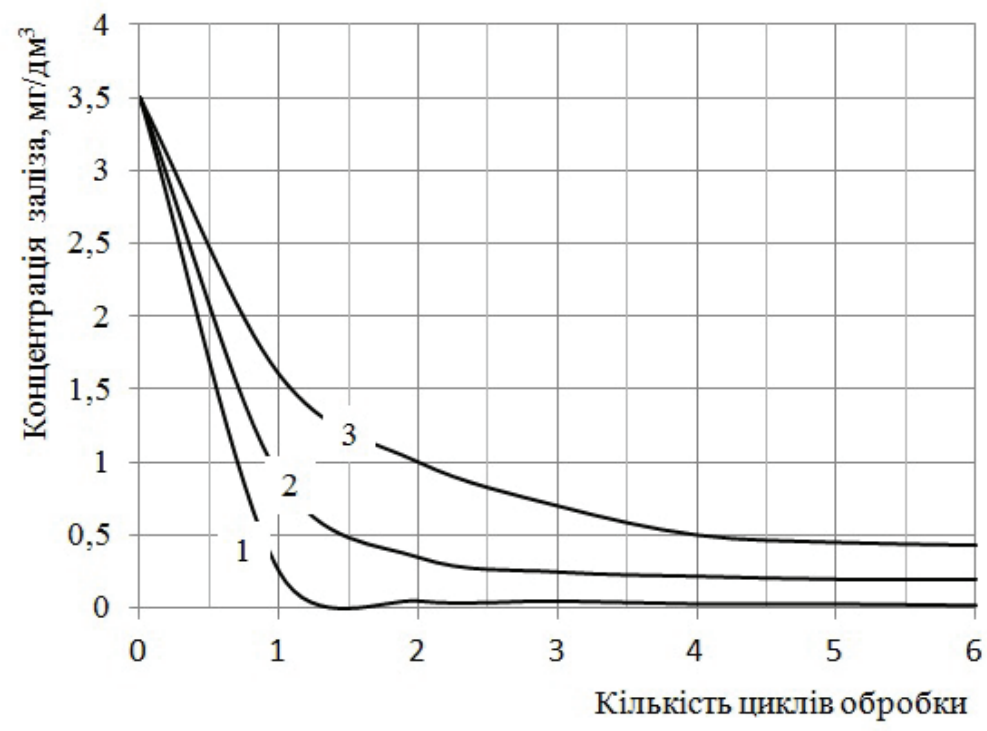

Рис. 3. Залежність зміни концентрації іонів заліза в воді від кількості циклів обробки при частоті пульсацій: 1 - 3,0; $2-2,5 ; 3-2,0$ кГц.

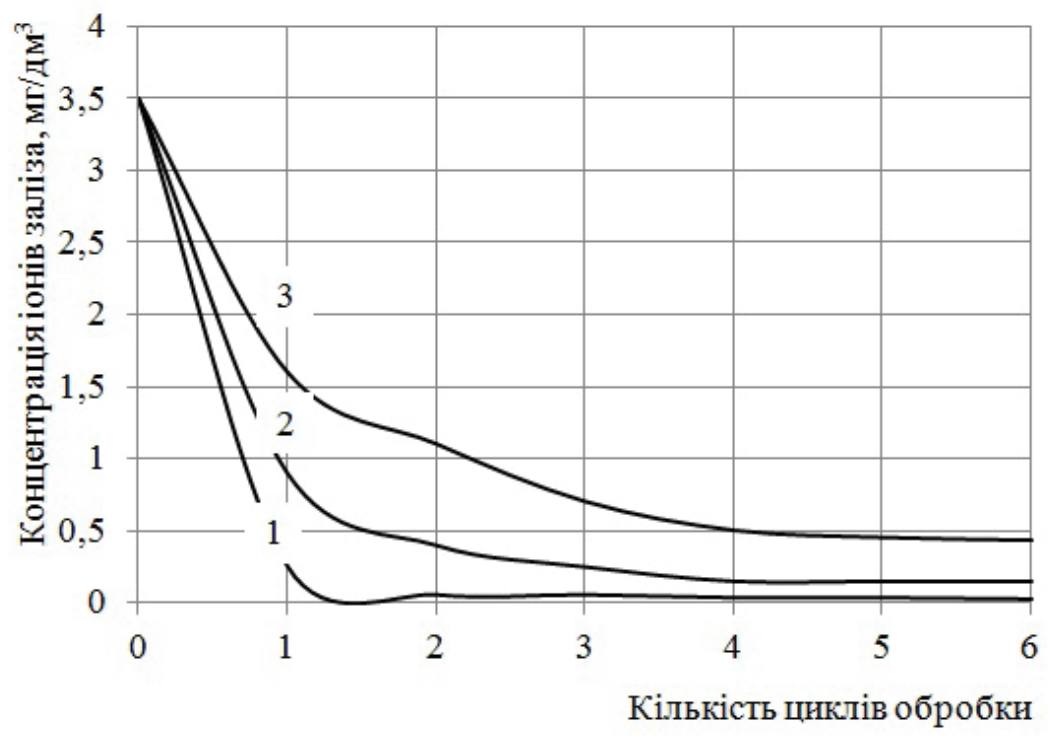

Рис. 4. Залежність зміни концентрації іонів заліза в воді від кількості циклів обробки при швидкості зсуву потоку: 1 - 50; 2 - 40; 3 - 30.10 $\mathrm{c}^{-1}$. 
Аналізуючи криві рис. 3 приходимо до висновку, що зміна частоти пульсацій потоку позначається на вмісті в ньому іонів заліза. При обробці води з частотою пульсацій 3 кГц за один цикл вміст іонів заліза зменшується від 3,5 до 0,2 мг/л. При зниженні частоти пульсацій до 2,5 кГц за 2 цикли обробки концентрація іонів заліза зменшується від 3,5 до 0,3 мг/л. Зменшення частоти пульсацій до 2,0 кГц призводить до ще гірших показників.

Ще одним 3 критеріїв оцінювання інтенсивності обробки води в аераторі-окислювачі є швидкість зсуву потоку. Цей показник об'єднує дві величини: швидкість руху потоку в радіальному напрямку і величину зазору між статором і ротором. При проведенні досліджень величину швидкості зсуву потоку змінювали в межах $(30 ; 40 ; 50) \cdot 10^{3} \mathrm{c}^{-1}$.

Криві зміни концентрації іонів заліза у воді в залежності від кількості циклів обробки при різній швидкості зсуву потоку представлені на рис. 4.

Криві, наведені на рис. 4, свідчать про те, що зі збільшенням швидкості зсуву потоку від 30 до $50 \cdot 10^{3} \mathrm{c}^{-1}$ швидкість знезалізнення води збільшується в 4 рази.

Так при швидкості зсуву потоку $30 \cdot 10^{3} \mathrm{c}^{-1}$ для знезалізнення води від 3,5 до 0,25 мг/л необхідно 4 цикли обробки, а при швидкості зсуву потоку $50 \cdot 10^{3} \mathrm{c}^{-1}-$ один.

Доведено, що керуючи гідродинамічними параметрами та змінюючи конструкційні особливості роторнопульсаційного вузла аератора-окислювача можна регулювати динаміку і якість очищення артезіанських вод від сполук заліза.

Швидке знезалізнення пояснюється тим, що вода, збагачена киснем повітря в процесі очищення, потрапляє в робочі органи апарата (ротор-статор-ротор). Водноповітряна суміш проходить скрізь щілинні отвори та зазори роторно-пульсаційного вузла піддається дії ударних хвиль, міжфазної турбулентності, мікрокавітації, кумулятивних струменів, вихорів, котрі викликають на міжфазних поверхнях нестійкості Релея-Тейлора або
Кельвіна-Гельмгольца, що призводить до інтенсивного дроблення бульбашок повітря, значному збільшенню сумарної поверхні контакту фаз і підвищенню процесів масо- i теплопереносу. Подібні ефекти, зазвичай, недосяжні при використанні традиційних методів при обробці дисперсних середовищ навіть при значно більшому рівні питомих енерговитрат. Проведені дослідження дозволяють зробити висновок про те, що застосування нового тепломасообмінного обладнання у вигляді аераційно-окислювальної установки роторного типу дозволить інтенсифікувати технологію очищення питної води.

\section{ЛІТЕРАТУРА}

1. Золотова Е.Ф. Очистка воды от железа, марганца, фтора и сероводорода/ Е.Ф. Золотова, Г.Ю. Асс. - М.: Стройиздат, $1975-176 \mathrm{c}$.

2. Таубе П.Р. Химия и микробиология воды / П.Р. Таубе, А.Г. Барабонова. - М: Высшая школа, 1983.-780 с.

3. Драгинский В.Л. Очистка подземных вод от соединений железа, марганца и органических загрязнений/ В.Л. Драгинский. // Водоснабжение и сантехника. -1997. - №12. - с.16.

4. Долінський А.А. Принцип дискретно-імпульсного введення енергії та його використання в технологічних процесах / А.А. Долінський. // Вісник АН УРСР. -1984. №1. - С. 39-46.

5. Долинский A.A. Использование принципа дискретно-импульсного ввода энергии для создания эффективных энергосберегающих технологий / А.А. Долинский. // ИФЖ. -1996. - Т. 69, №6. - С. 35-43.

6. Промтов М.A. Пульсационные аппараты роторного типа: теория и практика / М.А. Промтов. - М.: Машиностроение-1, 2001. - 260 с.

7. Долинский A.А. Метод дискретно - импульсного ввода энергии и его реализация / А.А. Долинский, А.Н. Ободович, Ю.А. Борхаленко. - Харьков: Вірованець А.П. “Апостроф”, 2012. - 184 с. 


\section{INTENSIFICATION OF THE PROCESSES OF AERATION AND OXIDATION IN A DRINKING WATER TREATMENT TECHNOLOGY BY NEW HEAT AND MASS TRANSFER EQUIPMENT}

\section{Dolinskyi A.A., Obodovych O.M., Pereiaslavtseva O.O., Sydorenko V.V.}

Institute of Engineering Thermophysics of the National Academy of Sciences of Ukraine,

2a, Zhelyabova str., Kyiv, 03680, Ukraine

Key words: artesian water, deferrization, aerator-oxidizer, frequency of pulsations, shear rate of flow.

The article presents experimental data on the deferrization of artesian water by air oxygen in a heat and mass transfer, aeration-oxidative setup of the rotor type. Dependences of the rate of deferrization on processing parameters are established.

References 7, figures 4, table 1.

1. Zolotova E.F. Purification of water from iron, manganese, fluorine and hydrogen sulphide / E.F. Zolotova, G.Yu. Ass. M., Stroyizdat, 1975. 176 p. (Rus.)

2. Taube P.R. Chemistry and microbiology of water/ P.R. Taube, A.G. Barabonova. M., Vyisshaya shkola, 1983. 780 p.(Rus.)

3. Draginskiy V.L. Purification of groundwater from iron, manganese and organic impurities/ V.L. Draginskiy. // Vodosnabzhenie i santehnika. 1997. №12. P.16. (Rus.)

4. Dolinskyi A.A. Principle of discrete-pulse energy input and its use in industrial processes. Visnyk AN URSR. 1984. №1. P. 39-46. (Ukr.)

5. Dolinskiy A.A. The use of the principle of discretepulse energy input for the creation of efficient energy-saving technologies / A.A. Dolinskiy. IFZh. 1996. T. 69, №6. P. 35-43.

6. Promtov M.A. Pulsating apparatuses of rotor type: theory and practice. M.A. Promtov. M., Mashinostroenie-1, 2001. 260 p.

7. Dolinskiy A.A., A.N. Obodovich, Yu.A. Borhalenko. The method of discrete-pulse energy input and its implementation. Harkov: VIrovanets A.P.“Apostrof”, 2012.$184 \mathrm{p}$. 